Г. Андрусяк,

кандидат юридичних наук, доцент кафедри кримінального права і процесу Східноєвропейського національного університету імені Лесі Українки

\title{
МОТИВ ТА МОТИВАЦІЯ ЗЛОЧИННОЇ ПОВЕДІНКИ ПІД ЧАС НЕОБХІДНОЇ ОБОРОНИ
}

Згідно з природно-правовим підходом, під час необхідної оборони особа, яка захищається, не усвідомлює суспільно небезпечного характеру своєї дії (оскільки тільки дією можна оборонятися), не передбачає іiі суспільно небезпечні наслідки. Особа діє свідомо на заподіяння шкоди особі, яка посягає, оцінюючи характер своїх дій як суспільно корисний. Метою дій особи, яка захищає себе чи інших осіб, є захист, який досягається лише шляхом заподіяння смерті особі, яка порушила кримінально-правову заборону. Такий підхід відповідає розумінню такого елемента вини, як іiі сутність. Нею визнається суспільна якість, що характеризується негативною оцінкою поведінки особи, яка вчинила злочин, і негативним ставленням винної особи до суспільних цінностей і благ - об'єктів кримінально-правової охорони. В діях особи у стані необхідної оборони відсутнє негативне ставлення до суспільних цінностей.

Правомірна поведінка може не бути суспільно корисною, однак і не бути суспільно небезпечною, а вважається соціально прийнятною, коли суспільство розглядає таку поведінку як більш-менш бажану. За соціально-правовим змістом вчинене діяння для суспільства може бути або небезпечним, або корисним, або допустимим (нейтральним). Якщо певні дії особи в конкретній ситуації кваліфікуються як суспільно небезпечні, це означає, що особа має інший шлях, інший варіант поведінки в цій ситуаціï, який є для суспільства корисним чи прийнятним. Держава не може надавати статус правомірної такій поведінці, яка завдає шкоду порядку суспільних відносин.

Діяння, вчинене за умов, які виключають його злочинність, $€$ вольовим і свідомим актом поведінки людини. Між усвідомленістю і волею існує певний взаємозв'язок, однак вони не взаємообумовлені. Як відомо, конкретна дія або бездіяльність, позбавлена психологічної основи діяння - свідомого і вольового елементів (рефлекторні вчинки), не є злочином.

Більшість правомірних і протиправних вчинків $€$ реалізацією усвідомлених рішень і здійснюється під контролем свідомості та волі суб'єкта. Через те слушним видається запитання, поставлене В.М. Кудрявцевим: чи означає викладене, що правове значення має лише поведінка, яка перебуває під контролем свідомості та волі, і що для права абсолютно байдужі або навіть протипоказані акти поведінки, породжені автоматизмом, інстинктом та іншими несвідомими проявами людської психіки?» Науковець дає відповідь на своє запитання: навіть у свідомій вольовій поведінці є елементи несвідомого [19, с. 69-71]. P.K. Русинов також вважає, що не можна протиставляти свідоме і несвідоме у психіці людини [20, с. 9].

Поведінка людини зумовлена цілою низкою факторів. Для того, щоб зовнішні фактори набули характеру 
мотиву, вони мають пройти через свідомість і волю особи. Саме тому таким важливим напрямом досліджень загальної психологічної теорії є мотивація людської поведінки. Українські науковціі констатують детермінуючий характер мотиву [1, с. 86; с. 23]. $\mathrm{У}$ психології мотив визначається як «упредметнена потреба» [2, с. 48]. Отже, мотивація починається з актуалізації певної потреби. У суб’єкта під вПливом потреби, що виникла, формується досить активний стан, який може пізніше перейти в мотив протиправної поведінки, зокрема в тих випадках, коли потреба, що виникла, не може бути реалізована законним шляхом. Дослідники наполягають на важливості мотиву, яким зумовлені діï, що становлять необхідну оборону, та відповідальність за перевищення і1 межі. Зокрема І.Я. Козаченко, аналізуючи санкції щодо заподіяння вбивства чи тяжких тілесних ушкоджень у разі перевищення меж необхідної оборони, зазначає: «Саме враховуючи мотиви вчинення злочину (і певною мірою й мету), законодавець передбачив за ї вчинення санкції із досить пільговими видами і розмірами покарання порівняно 3 випадками спричинення таких самих наслідків, але, скажімо, 3 мотивів ревнощів, помсти тощо» [3, с. 176]. Наголосимо на зв'язку мотиву й мети. Науковці визначають, що мотив призводить до постановки цілі, але не $€$ нею [4, с. 43].

Так, під мотивацією розуміють систему спонукань людини, спрямовану на досягнення конкретних цілей [5, с. 96]. Розглядаючи склад вчинку, що виключає злочинність діяння, А.Ю. Шурдумов наголошує, що «кожен такий вчинок має певні соціально схвалювані (корисні, допустимі) цілі [6, с. 13]. Мета - це уявлення суб'єкта про результати його діяльності, до яких він прагне. Вона часто буває пов'язана з навколишнім середовищем, одним із проявів якого $€$ ситуація. Тому дія, спрямована на досягнення цілі, змінює і середовище, отже, і ситуацію... [7, с. 7]. Слід також відзначити, що будь-яка діяльність людини є полімотивованою. Дослідники $Ф$. Сафуанов і $Є$. Васке зазначають: «аналіз мотивацій злочинної поведінки ... показав, що у більшості випадків вона має характер полімотивованої за наявності провідного, домінуючого мотиву» [23]. На полімотивованості поведінки особистості акцентує також увагу український правознавець В. Тимошенко, зазначаючи, що за кожним вчинком або за усвідомленим бажанням стоять кілька мотивів [24, с. 65]. Російський правознавець Г. Шиханцов також вважає протиправну поведінку в переважній більшості випадків полімотивованою, описуючи три мотиви: мотив виміщення, під дією якого відбувається перенесення своєї агресії, озлобленості на сторонніх осіб; мотив заміщення, що реалізується через зняття напруги; мотив помилкового самоствердження, що виражається в хибному, збоченому утвердженні себе шляхом приниження, пригнічення особистості інших, насильства над ними, гіперкомпенсації [25, с. 133].

Разом 3 тим у сфері практичної поведінки людини діють правила, які природно визначають порядок людських взаємовідносин унаслідок існування природжених людських нахилів, інстинктів, серед яких є інстинкт самозбереження [8, с. 15]. Недарма юристи, які досліджують проблеми мотивів у кримінальному праві, відзначають, що специфіка мотиву та мотивації злочину вимагає поглиблених досліджень із залученням новітніх досягнень психології, соціології, етики, інших галузей знань [9, с. 2]. Дослідники необхідної оборони справедливо наголошують, що право на захист - одне з невід'ємних, природних прав людини, оскільки базується на притаманних будь-якій живій істоті інстинктах самозбереження, батьківства, власності, стадності (збереження виду). Невипадково воно 
реалізується найчастіше під час посягання на того, хто обороняється, посягання на іншу особу, а також на права і свободи третіх осіб, родичів чи знайомих $[10$, с. 15-16]. Такий підхід, що пов'язує поняття несвідомого мотиву та інстинкт самозбереження, є правильним. У разі виникнення загрози життю, здоров'ю, статевій свободі чи недоторканості застосування захисних дій визначається не лише свідомими мотивами, а й на підсвідомому рівні - на основі інстинктів, оскільки протиправна поведінка часто виступає результатом саме неусвідомлених мотивів. На думку Ю. Антоняна, ступінь залежності особистості від умов, які іï оточують, пропорційний імовірності вчинення злочинних дій. Така залежність керує поведінкою особистості настільки, наскільки суб'єкт не усвідомлює іiі існування [21, с. 111].

Російський правознавець В. Васильєв також виділяє серед категорій мотивів злочинної поведінки неусвідомлювані мотиви, які, на його думку, властиві певному типу особистості та характеризуються переоцінкою особистістю своєї значущості, агресивним ставленням до навколишнього середовища, нестійкістю настроїв [22, с. 403].

Доведено існування неусвідомлених елементів мотиваціі, що насамперед стосується інстинктивних реакцій самозахисту, спрямованих на збереження цілісності організму. Так, в українській мові «інстинкт» тлумачиться як «несвідоме й нездоланне прагнення, потяг до чого-небудь» [11, с. 792]. Необхідна оборона як акт людської поведінки базується на інстинкті живих істот захищати себе від небезпеки [12, с. 61]. Разом з тим не можна не погодитися з тезою про те, що людина наділена надзвичайною можливістю опосередковувати у своій свідомості все те, що спонукає ii до діяльності [13, с. 47]. Тому несвідомий елемент поведінки має правове значення лише в тих випадках і межах, в яких він піддається мож- ливому контролю з боку свідомості та волі особи, тобто потенційно може усвідомлюватися в потрібний момент [14, с. 72].

Д.І. Масол у своєму дослідженні, здійснюючи детальний огляд позицій науковців щодо сутності мотиву, доходить до категоричного й помилкового з огляду на наші узагальнення висновки, що відмова від розуміння мотиву злочину лише як усвідомленого спонукання не відповідає основам учення про злочин і склад злочину [15, с. 87]. Існування неусвідомлених елементів мотивації, зокрема інстинктивних реакцій самозахисту, є незаперечним.

Як відомо, розроблено багато класифікацій мотивів у науці кримінального права, кримінології тощо. Не існує уніфікованого підходу щодо соціальної сутності мотивів злочинів. Так, В.В. Лунєєв відзначав, що деякі дослідники вважають усі мотиви злочинів суспільно небезпечними, інші - крім суспільно небезпечних виокремлюють мотиви суспільно нейтральні та суспільно корисні, а деякі науковці знаходять, що мотиви злочинної поведінки переважно суспільно нейтральні [16, с. 49]. Не вдаючись до детального аналізу цих класифікацій, оскільки це не $€$ завданням нашого дослідження, підтримуємо запропонований П.С. Дагелем і схвалений А.В. Савченком перелік мотивів: 1) суспільно-негативні (низькі) мотиви злочину; 2) суспільно-нейтральні мотиви; 3) суспільно-позитивні мотиви [17, с. 9].

Сучасні дослідники суспільно корисної мотивації навіть пропонують внесення змін до переліку обставин, що пом'якшують покарання, шляхом введення норми, яка обов'язково має враховуватися судом під час призначення покарання. Частину першу статті 66 KK України пропонується доповнити пунктом 10 такого змісту: «10 вчинення злочину із суспільно корисною мотивацією» [18, с. 9]. Підтримуємо таку позицію. Хоча за визначеним у частині 2 статті 66 KK України принципом суд може пом'як- 
шити покарання з урахуванням інших обставин, не зазначених у частині першій цієї статті і спеціально не вказаних у законі, однак нині в законодавстві не закріплено припису, який зобов'язує суд ураховувати суспільно корисну мотивацію під час призначення покарання. Натомість чітко зазначено, що суд не може не враховувати зазначені в законі обставини, які пом'якшують покарання, тому внесення пропонованої норми гарантуватиме особі таке пом'якшення.

Отже, проаналізовані обставини насамперед $€$ вольовими і свідомими діяннями людини, детермінованими суспільно-позитивними або суспільно-нейтральними мотивами й цілями. Мотивація дій винної людини в разі перевищення меж необхідної оборони має бути насамперед зумовлена захистом від суспільно небезпечного посягання захищених законом прав та інтересів. Мотив у разі необхідної оборони має суспільно-позитивний характер (прагнення захистити права та інтереси), тоді як, наприклад, у разі вчинених дій у стані афекту мотив має суспільно-негативний характер (помста).

Ми підтримуємо відому в науці кримінального права ідею про перевагу особистих благ особи, яка захищається, над благами особи, яка посягає, чим сама ставить свої блага (життя чи здоров'я) під загрозу. Допустимим $є$ захист менш цінного блага шляхом заподіяння шкоди більш цінному благу того, хто є джерелом посягання. Наприклад, жінка, яка під час захисту статевої свободи заподіяла смерть нападнику, зазвичай притягається до кримінальної відповідальності, оскільки вчинене нею діяння безпідставно кваліфікується судами за ст. 118 чи ст. 124 KK України. Без належного мотивування заподіяння тяжких тілесних ушкоджень або смерті під час захисту статевої свободи чи недоторканості особи кваліфікується як перевищення меж необхідної оборони, оскільки жінкою спричинена шкода життю чи здоров'ю і водночас відвернена шкода статевій свободі чи статевої недоторканості.

Посягання на статеву свободу чи недоторканість жінки часто є наслідком виникнення у гвалтівника умислу приховати скоєне згвалтування шляхом умисного вбивства потерпілої. Відтак заподіяння смерті особі, яка намагається згвалтувати жінку, може бути визнано правомірним.

Зростання рівня злочинності, зокрема статевої і насильницької, сучасні тенденціі незастосування судами норми про необхідну оборону під час посягання на статеву свободу чи статеву недоторканість особи, що обумовило притягнення до кримінальної відповідальності осіб, які реалізовували своє природне право на самозахист, детермінують потребу критичного переосмислення визначення меж необхідної оборони на законодавчому рівні.

Відповідно до цього ми пропонуємо таке визначення поняття: необхідна оборона - це вольова і свідома дія людини, детермінована суспільно-позитивними мотивами й цілями, а також природними (інстинктивними) реакціями людини. Саме вплив інстинктивних реакцій видається нам особливо важливим, оскільки це природно-правова сутність права особи на необхідну оборону. Необхідна оборона має дві мети: найближча (перша, проміжна) - відвернення чи припинення посягання, кінцева (друга) - захист правоохоронних інтересів особи, суспільства, держави.

Перевищенням меж необхідної оборони визнається умисне заподіяння тому, хто посягає, смерті або тяжких тілесних ушкоджень, які не відповідають суспільній небезпеці посягання або обстановці захисту. Перевищення меж необхідної оборони тягне за собою кримінальну відповідальність у випадках, спеціально передбачених у статтях 118 та 124 цього Кодексу. 
У разі виникнення загрози життю, здоровю, статевій свободі чи недоторканості застосування захисних дій детермінується не лище свідомими мотивами, але й на підсвідомому рівні - на основі інстинктів. У статті ми намагаємося довести існування неусвідомлених елементів мотивації, які насамперед стосуються інстинктивних реакцій самозахисту, спрямованих на збереження иілісності організму. Необхідна оборона як акт людської поведінки базується на інстинкті живих істот захищати себе від небезпеки. Необхідна оборона є вольовою $і$ свідомою дією людини, детермінованою соиіально-позитивними мотивами й цілями, а також природними (інстинктивними) реакціями людини. Це особливо важливо у контексті природності права особи на необхідну оборону.

Правомірна поведінка може не бути суспільно корисною, однак $і$ не бути суспільно небезпечною, а соціально прийнятною, коли суспільство розглядає таку поведінку як більш-менш бажану.

Правильне розуміння мотиву та мотивації злочинної поведінки сучасні дослідники суспільно корисної мотивації пропонують внесення змін до переліку обставин, які пом'якшують покарання, шляхом введення норми, що обов'язково має враховуватися судом під час призначення покарання. У чій статті ми також пропонуємо зміну норми статті, а також визначення $i$ суті таких понять як мотив, мотивація, інстинкт, злочинна поведінка, самозахист та, зрештою, визначення поняття «необхінна оборона» та «перевищення меж необхідної оборони».

До вітчизняних $i$ зарубіжних науковців, які присвятили свої праці проблемам мотивів та мотивації злочинної поведінки, відносяться Ю.М. Антонян, Б.М. Голов- кін, В. Васильев, О.В. Ткачова, B. Тимошенко, А.В. Савченко, Н.Б. Хлистова, А. Ф. Зелинський. Мета роботи - дослідження проблеми мотивів $i$ мотивації у кримінальному праві, зокрема в контексті необхідної оборони із залученням новітніх досягнень психології, соціологіï, етики та інших галузей знань.

Ключові слова: мотив; мотивація; злочинна поведінка; правомірна поведінка; інстинктивна реакція самозахисту; суспільно корисна мотивація; необхідна оборона, перевищення меж необхідної оборони.

Andrusiak G. Motive and motivation of criminal behavior in necessary defense

When there is a threat to life, health, sexual freedom or inviolability of protective actions, it is determined not only by conscious motives, but also on a subconscious level - on the basis of instincts. In this article we will try to prove the existence of unconscious elements of motivation, which primarily concerns the instinctive reactions of self-defense, aimed at preserving the integrity of the organism. Necessary defense as an act of human behavior is based on the instinct of living beings to protect themselves from danger. Necessary defense is a volitional and conscious human action, which is determined by socially positive motives and goals, as well as natural (instinctive) human reactions. This is especially important in the context of the naturalness of a person's right to self-defense.

Legitimate behavior may not be socially useful, but it may not be socially dangerous, but socially acceptable, when society considers such behavior as more or less desirable.

Proper understanding of the motive and motivation of criminal behavior modern researchers of socially useful motivation suggest making changes to the list of mitigating circumstances 
by introducing a rule that must be taken into account by the court when sentencing. In this article, we also propose a change in the norm of the article; definition and essence of such concepts as motive, motivation, instinct, criminal behavior, selfdefense and finally definition of the concept of necessary defense and exceeding the limits of necessary defense.

Domestic and foreign scientists who have dedicated their work to the problems of motives and motivation of criminal behavior: Yu.M. Aнтонян, Б.M. Golovkin, V. Vasiliev, O.V. Tkachova, V. Tymoshenko, A.V. Savchenko, NB Khlistova, AF Zelinsky. The purpose of the article is to study the problem of motives and motivation in criminal law, in particular in the context of the necessary defense with the involvement of the latest advances in psychology, sociology, ethics and other fields of knowledge.

Key words: motive; motivation; criminal behavior; lawful behavior; instinctive reaction of self-defense; socially useful motivation; necessary defense, exceeding the limits of necessary defense.

\section{Література}

1. Зелинский А. Ф. Криминология : курс лекцій. Харьков: Прапор, 1996. 260 c.

2. Костенко А. Н. Принщип отражения в криминологии (психологический механизм криминального поведения). Київ : Наукова думка, 1986. 128 с.

3. Асмолов А. Г. Психология индивидуальности, Москва : Изд-во Московского ун-та, 1986. $96 \mathrm{c}$.

4. Козаченко И. Я. Санкици за преступления против жизни и здоровья: обусловленность, структура, функции, виды. Томск : Изд-во Томского ун-та, 1987. 232 c.

5. Механизм преступного поведения. Москва: Наука, 1981. 247 с.

6. Чуфаровский Ю. В. Юридическая психология, Москва : Право и закон, 1997. $320 \mathrm{c}$.

7. Шурдумов А. Ю. Понятие обстоятельств, исключающих преступность дея- ния : науч.-популярное издание. Нальчик : Издательский центр «Эль-Фа», 2000. 55 c.

8. Антонян Ю. М. Роль конкретной жизненной ситуащии в совершении преступления : учеб. пособие. Москва : Изд-во Академии МВД СССР, 1973. 71 с.

9. Гориславський К. О. Право людини та громадянина на самозахист життя i здоров'я від протиправних посягань : дис. ... канд. юрид. наук : 12.00.02. Донеиьк, 2003. C. 35-38.

10. Савченко A. В. Мотив і мотивація злочину : автореф. дис. ... канд. юрид. наук : спеи. 12.00 .08 «Кримінальне право та кримінологія; кримінально-виконавче право». Київ, 1999. 18 с.

11. Бондарук О. М. Необхідна оборона при посяганні на власність: дис. ... канд. юрид. наук : 12.00.08. Київ, 2012. 230 c.

12. Новий тлумачний словник української мови : в $3 \mathrm{~m}$. / уклад.: В. Яременко, О. Сліпушко. 2-е вид., виправ. Київ : Вид-во «AKOHIT», 2008. T. 1: A-K-П. 928 c.

13. Юшков Ю. Н. Ннститут необходимой обороны и его роль в борьбе с преступностью в современных условиях. Государство и право. 1992. № 4. С. 61.

14. Волков Б. С. Детерминистическая природа преступного поведения. Казань: Изд-во Казанского ун-та, 1975. 110 c.

15. Кудрявиев В. Н. Избранные труды по специальным наукам : в $3 \mathrm{~m}$. Москва: Наука, 2002. Т. 1: Общая теория права. Уголовное право. 2002. 567 с.

16. Масол Д. І. Мотиви расової, національної чи релігійної нетерпимості у кримінальному праві України : дис. ... канд. юрид. наук:12.00.08. Київ, 2014. 237 c.

17. Лунеев В.В. Мотивация преступного поведения. Москва : Наука, 1991. $383 \mathrm{c}$.

18. Савченко А. В. Мотив і мотивація злочину : автореф. дис. ... канд. юрид. наук : спеи. 12.00.08 «Кримінальне право та кримінологія; кримінально-виконавче право». Київ, 1999. 18 с.

19. Хлистова Н.Б. Заохочення суспільно корисної мотивації: кримінальноправові та кримінологічні аспекти : дис. ... канд. юрид. наук: 12.00.08. Донецьк, 2008. 209 с.

20. Кудрявцев В. Н. Избранные труды по специальным наукам : в $3 \mathrm{~m}$. Москва: Наука, 2002., Т. 1: Общая теория права. Уголовное право. 2002. 567 с.

21. Русинов Р. К. Сознание и правомерное поведение. Советское государство и право. 1983. № 5. С. 3-10. 
22. Антонян Ю. М., Кудрявцев В.Н., производстве. Психологические исследоЭминов В.Е. Личность пре ступника. СПб.: вания: электрон. науч. журнал., 2009. Юридический центр Пресс, 2004. 366 с.

23. Будіянський М. Ф. Психологія особистості : нави.-метод. посіб. Одеський держ. ун-т ім. I. І.Мечникова, Iн-т математики, економіки та механіки. , Одеса: Acmponpurm, 1999. 112 C.

24. Сафуанов Ф. С., Васкэ Е.В. Определение мотивации преступного поведения несовершеннолетних в уголовном судо№ 5(7). URL: http://psystudy.ru/index. php/num/2009n5-7/227-safuanov7.html

25. Тимошенко B. I. Протиправна поведінка: визначення та мотивація. Бюлетень Міністерства юстиції України. 2011. № 12. С. 61-67.

26. Шиханцов Г. Г. Юридическая психология : учеб. для вузов. Изд. 2-е. Москва: Зериало-М, 2006. 272 с. 